\author{
Zh.A. Sartabanov, A.Kh. Zhumagaziyev, G.A. Abdikalikova \\ K. Zhubanov Aktobe Regional State University, Kazakhstan \\ (E-mail: sartabanov42@mail.ru)
}

\title{
Multiperiodic solution of linear hyperbolic in the narrow sense system with constant coefficients
}

\begin{abstract}
There is researched existential problem of a unique multiperiodic in all independent variables solution of a linear hyperbolic in the narrow sense system of differential equations with constant coefficients and its integral representation in vector-matrix form. To solve this problem, based on Cauchy's method of characteristics, a constructing methodology for solutions of initial problem system under consideration with various differentiation operators in vector fields directions of independent variables space has been developed based on projectors. Using this method, Cauchy problems for linear system with integral representation are solved. The introduced projectors by definition characteristic had significant value. By solving the main problem necessary and sufficient conditions for existence of multiperiodic solutions linear homogeneous systems other than trivial are established. The conditions are obtained for absence of nonzero multiperiodic solutions of these systems. In absence of nonzero multiperiodic solutions linear homogeneous systems, the main theorem on existence and uniqueness of multiperiodic solution linear nonhomogeneous system with derivation of its integral representation depending on projection operators is proved. The developed method has prospect of extending the results to quasilinear system under consideration, as well as to multidimensional vector $t=\left(t_{1}, \ldots, t_{m}\right)$ and multiperiodic matrices at partial derivatives of unknown vectorfunction.
\end{abstract}

Keywords: hyperbolic system in the narrow sense, multiperiodic solution, method of characteristics, projection operators, differentiation operators by vector fields, integral representation.

\section{Introduction}

Solving many problems of modern science and technology, one often has to deal with oscillatory processes, which are described by partial differential equations. In this regard, the study of oscillatory processes described by single and multifrequency periodic solutions of differential equations systems has important theoretical and applied value. It is known that the basis of theory oscillatory solutions of differential equations originates from the classical works of A.M. Lyapunov, A. Poincare, N.M. Krylov, N.N. Bogolyubov, Yu.A. Mitropolsky, A.M. Samoilenko, A.N. Kolmogorov, V.I. Arnold, Yu. Moser et al.

Methods for integrating systems of quasilinear differential equations with the same main part regarding this note are described in [1-6]. Note that the integration of quasilinear differential equations systems with different principal parts refers to little-studied problems in the sections of the theory partial differential equations. Therefore, the development of methods for solving problems of multiperiod solutions of such systems is at the initial stage of its development. It is known that the basis of theory multiperiodic solutions of partial differential equations systems with one differentiation operator was laid in [4-10]. Some ideas of the methods of these works, based on research [11-14], were extended in [15-17] to the study of problems on multiperiodic solutions of quasilinear equations systems with various differentiation operators along their characteristics.

In [15], the question of almost multiperiodic solutions of systems with small nonlinearity is studied, when the matrix of coefficients of the linear part has a triangular form, and the differentiation operators are row-wise different.

In the study [16], a quasilinear system with two differentiation operators is considered and the conditions for the existence of unique multiperiodic solution this system are established in the noncritical case. 
In a note [17], multiperiodical in wide extent solutions of the periodic boundary value problem for linear systems that decompose into linear subsystems with various differentiation operators along the directions of vector fields of spatial variables are studied.

The issues of solutions of quasilinear equations systems that are almost periodic in time variable, the linear parts of which decompose into independent subsystems with its differentiation operators, were researched in the monograph [6] in terms of the matricant.

Splitting the linear part into independent subsystems is a very special case in which the problems under consideration are solved. Consequently, these tasks remain open to the general case.

In [18-20], the problems on multiperiodic solutions are investigated by introducing a projection operator. The aim of this paper is to substantiate the method of the projection operator for studying an initial and a multiperiodic problems the linear hyperbolic in the narrow sense systems with constant coefficients.

It is known that the basis of the general theory of partial differential equations systems are methods for studying linear systems. Moreover, in the oscillations theory of continuous medium of noninteracting particles, problems associated with the study of its vibrations mainly lead to the study of multiperiodic solutions of linear equations systems. In most cases, linear equations, in comparison with nonlinear ones, are considered to be studied quite widely and deeply. But these linear problems are so diverse that among them there are either poorly studied or generally unstudied until today. The latter also includes the problem that was posed above for linear systems.

Let the oscillatory process in the continuous medium be described by system of equations

$$
\frac{\partial y}{\partial \tau}+A \frac{\partial y}{\partial t}=B y+\varphi(\tau, t)
$$

where $y=\left(y_{1}, \ldots, y_{n}\right)$ is unknown vector-function; $\tau \in(-\infty,+\infty)=R$ and $t \in R ; A$ and $B$ are constant $n$-matrices; $\varphi(\tau, t)$ is $n$-vector function.

The initial-boundary value problems for system in the form (1) have been studied in various literature, in particular, in monographic works [1-3], with constant and variable coefficients in terms of solutions in the wide extent, and a detailed study has been carried out for systems in the scalar form.

In this paper, we consider the problem of existence and integral representation in the vector-matrix form of a unique $(\theta, \omega)$-periodic solution of system $(1)$ with the following assumptions:

$1^{0}$. The matrix $A$ has various real eigenvalues $\lambda_{j}=\lambda_{j}(A), j=\overline{1, n}$ :

$$
\lambda_{j} \neq \lambda_{k}, \quad j, k=\overline{1, n}, \quad \lambda_{j} \in R .
$$

System (1) under condition (2) is called hyperbolic in the narrow sense [2].

$2^{0}$. Matrix $B$ satisfies the relation

$$
\operatorname{det}[Y(\theta)-E] \neq 0 .
$$

Here $Y(\tau)=\exp [B \tau], E$ is identity matrix.

Under condition (3), homogeneous system corresponding to system (1) has no $(\theta, \omega)$-periodic solutions, except for the trivial one.

$3^{0}$. The vector-function $\varphi(\tau, t)$ has properties of $(\theta, \omega)$-periodicity and smoothness with respect to $(\tau, t)$ order $(0,1)$ :

$$
\varphi(\tau+\theta, t+q \omega)=\varphi(\tau, t) \in C_{\tau, t}^{(0,1)}(R \times R), \quad q \in Z,
$$

where $\theta$ and $\omega$ are rationally independent periods; $Z$ is the set of integers; $C_{\tau, t}^{(0,1)}(R \times R)$ is the class of functions possessing the indicated smoothness properties in order $(0,1)$. 


\section{Main Results}

By linear replacement

$$
y=C x
$$

with nondegenerate constant $n$-matrix $C$ the system (1) is reduced to form

$$
\frac{\partial x}{\partial \tau}+J \frac{\partial x}{\partial t}=K x+f(\tau, t)
$$

where $x=\left(x_{1}, \ldots, x_{n}\right) ; \quad C^{-1} A C=J \equiv \operatorname{diag}\left[\lambda_{1}, \ldots, \lambda_{n}\right] ; \quad C^{-1} B C=K$ is constant $n$-matrix and $C^{-1} \varphi(\tau, t)==f(\tau, t)$ is vector-function.

Matrix $X(\tau)$ in the form of

$$
X(\tau)=\exp [K \tau]=\exp \left[C^{-1} B C \tau\right]=C^{-1} \exp [B \tau] C=C^{-1} Y(\tau) C
$$

is matricant of system

$$
\frac{\partial x}{\partial \tau}+J \frac{\partial x}{\partial t}=K x
$$

and $X(0)=E$.

Denote vector-function $f(\tau, t)=C^{-1} \varphi(\tau, t)$, the same like $\varphi(\tau, t)$, has properties $(\theta, \omega)$-periodicity and smoothness of order $(0,1)$ :

$$
f(\tau+\theta, t+q \omega)=f(\tau, t) \in C_{\tau, t}^{(0,1)}(R \times R) .
$$

This can easily be verified on the basis of condition (4).

To study the main question, it is necessary to solve the problem for system (7) with the initial condition

$$
\left.x\right|_{\tau=\tau_{0}}=u(t) \in C_{t}^{(1)}(R) .
$$

Obviously, by virtue of the statement of problem $(7)-\left(7^{0}\right)$, we are dealing with differentiation operators $D=\left(D_{1}, \ldots, D_{n}\right)$, that coordinate-wise act on vector-function $x(\tau, t)=\left(x_{1}(\tau, t), \ldots, x_{n}(\tau, t)\right)$ with the property of smoothness $(1,1))$ with respect to $(\tau, t)$ in the form

$$
D x(\tau, t)=\left(D_{1} x_{1}(\tau, t), \ldots, D_{n} x_{n}(\tau, t)\right) .
$$

As can be seen from system (7), on the left side these differentiation operators $D_{j} x_{j}, j=\overline{1, n}$ are defined as

$$
D_{j} x_{j} \equiv \frac{\partial x_{j}}{\partial \tau}+\lambda_{j} \frac{\partial x_{j}}{\partial t}=0, \quad j=\overline{1, n},
$$

which in the directions of corresponding vector fields

$$
\frac{d t}{d \tau}=\lambda_{j}, \quad j=\overline{1, n}
$$

act like a normal differentiation operator with respect to $\tau$.

Each of the equations (10), which determines the direction of differentiation, can be called the characteristic equation of operator $D_{j}=\frac{\partial}{\partial \tau}+\lambda_{j} \frac{\partial}{\partial t}$. Then the general solution

$$
t=\sigma+\lambda_{j}(\tau-s) \equiv h_{j}(\tau, s, \sigma), \quad j=\overline{1, n}
$$

defines the characteristic $h_{j}(\tau, s, \sigma)$ of operator $D_{j}$ coming from initial point $(s, \sigma) \in R \times R$. 
Thus, for characteristics, we have a common notation $h(\tau, s, \sigma)$, which as values can take one of the known characteristics $h_{j}(\tau, s, \sigma), j=\overline{1, n}$. Therefore, we have

$$
h(\tau, s, \sigma) \in\left\{h_{1}(\tau, s, \sigma), \ldots, h_{n}(\tau, s, \sigma)\right\},
$$

where $\left.h_{j}(\tau, s, \sigma)\right|_{\tau=s}=\sigma$.

Obviously, the operators $D_{j}$ move on to the total derivative operator $\frac{d}{d \tau}$ with respect to $\tau$, along the characteristics $t=h_{j}(\tau, s, \sigma)$ defined by relation (11) and we have

$$
\begin{gathered}
\left.D x\right|_{t=h(\tau, s, \sigma)}=\left(\left.D_{1} x_{1}\right|_{t=h_{1}(\tau, s, \sigma)}, \ldots,\left.D_{n} x_{n}\right|_{t=h_{n}(\tau, s, \sigma)}\right)= \\
=\left(\frac{d}{d \tau} x_{1}\left(\tau, h_{1}(\tau, s, \sigma)\right), \ldots, \frac{d}{d \tau} x_{n}\left(\tau, h_{n}(\tau, s, \sigma)\right)\right)=\frac{d}{d \tau} x(\tau, h(\tau, s, \sigma)) .
\end{gathered}
$$

Thus, a relationship is established that expressed by relation (13) between the differentiation operator $D$ acting by formula (8) and the total derivative $\frac{d}{d \tau}$ of the vector-function $x(\tau, t)$ along characteristics (11)-(12).

Next, to ensure output of function defined on characteristics $h(\tau, s, \sigma) \in\left\{h_{1}(\tau, s, \sigma), \ldots, h_{n}(\tau, s, \sigma)\right\}$ in the space of variables $(\tau, t)$, from the characteristics (11) we determine the first integrals

$$
h_{j}(s, \tau, t)=\sigma, \quad j=\overline{1, n}
$$

of characteristic systems (10) and we have

$$
h(s, \tau, t) \in\left\{h_{1}(s, \tau, t), \ldots, h_{n}(s, \tau, t)\right\} .
$$

It's obvious that

$$
D_{j} h_{j}(s, \tau, t)=0, \quad j=\overline{1, n} .
$$

Moreover, if $H_{j}(t)$ an arbitrary differentiable function, then

$$
D_{j} H_{j}\left(h_{j}(s, \tau, t)\right)=0,(s, \tau, t) \in R \times R \times R, \quad j=\overline{1, n} .
$$

Thus, if the function $x(\tau, t)=\left(x_{1}(\tau, t), \ldots, x_{n}(\tau, t)\right)$ is defined along the characteristics (11)-(12):

$$
\left(x_{1}\left(\tau, h_{1}(s, \tau, \sigma)\right), \ldots, x_{n}\left(\tau, h_{n}(s, \tau, \sigma)\right)\right),
$$

then in respect that (14) from function (17) we obtain the function $x(\tau, t)$ defined as $(\tau, t) \in R \times R$, by virtue of the relations

$$
h_{j}\left(\tau, s, h_{j}(s, \tau, t)\right)=h_{j}(\tau, \tau, t)=t, \quad j=\overline{1, n} .
$$

The rightness of relations (18) is easily verified on the basis of (11) and (14).

We begin the integration of system (7) from the system

$$
\frac{\partial x}{\partial \tau}+J \frac{\partial x}{\partial t}=0
$$

with unknown vector-function $x=\left(x_{1}, \ldots, x_{n}\right)$.

By virtue of (8)-(9) and (13) system (19) can be represented as

$$
D x=0
$$

or in scalar form

$$
D_{j} x_{j}=0, \quad j=\overline{1, n} .
$$


Then, by virtue of identities (15)-16), we have the basic solution

$$
x(s, \tau, t)=\left(h_{1}(s, \tau, t), \ldots, h_{n}(s, \tau, t)\right)
$$

with coordinates

$$
x_{j}=h_{j}(s, \tau, t), \quad j=\overline{1, n},
$$

satisfying the initial conditions

$$
\left.h_{j}(s, \tau, t)\right|_{\tau=s}=t
$$

and general solution

$$
x(s, \tau, t)=H(h(s, \tau, t)) \equiv\left(H_{1}\left(h_{1}(s, \tau, t)\right), \ldots, H_{n}\left(h_{n}(s, \tau, t)\right)\right)
$$

with arbitrary differentiable $n$-vector-function $H(t)=\left(H_{1}(t), \ldots, H_{n}(t)\right)$.

Then the solution $x$ of system (19) with the initial condition

$$
\left.x\right|_{\tau=\tau^{0}}=u(t)
$$

and the vector-function $u(t)=\left(u_{1}(t), \ldots, u_{n}(t)\right) \in C_{t}^{(1)}(R)$ is determined by relation (22) by choosing an arbitrary vector-function $H(t)=u(t)$.

Consequently,

$$
x\left(\tau^{0}, \tau, t\right)=u\left(h\left(\tau^{0}, \tau, t\right)\right) \equiv\left(u_{1}\left(h_{1}\left(\tau^{0}, \tau, t\right)\right), \ldots, u_{n}\left(h_{n}\left(\tau^{0}, \tau, t\right)\right)\right)
$$

represents a solution of the initial problem $(19)-\left(19^{0}\right)$, otherwise, relation (23) can be called the zero of the operator $D$ with initial condition $\left(19^{0}\right)$.

Thus, we have the following statement.

Theorem 1. A solution of the initial problem $(19)-\left(19^{0}\right)$ is determined by the relation (23).

Hence we have an obvious consequence.

Corollary. In the case of narrow hyperbolicity of system (1), the vector-function $y=C x\left(\tau^{0}, \tau, t\right)$ is a solution of equation

$$
\frac{\partial y}{\partial \tau}+A \frac{\partial y}{\partial t}=0
$$

satisfying the initial condition $\left.y\right|_{\tau=\tau^{0}}=C u(t)$,

where $C$ is the transformation matrix $(5) ; x\left(\tau^{0}, \tau, t\right)$ is the solution to problem $(19)-\left(19^{0}\right)$.

Now we consider the system of homogeneous equation (7) with the initial condition $\left(7^{0}\right)$.

Let the matrix be represented in the form $X(\tau)=\left[x_{j k}(\tau)\right]_{1}^{n}, k=\overline{1, n}$. Then, using the $n$-vectorfunctions $X_{j}(\tau)=\left(x_{j 1}(\tau), \ldots, x_{j n}(\tau)\right), j=\overline{1, n}$, composed from rows of matrix $X(\tau)$, we have its vector representation

$$
X(\tau)=\left(\begin{array}{c}
X_{1}(\tau) \\
\ldots \\
X_{n}(\tau)
\end{array}\right) .
$$

Next, based on the initial vector-function $u(t)=\left(u_{1}(t), \ldots, u_{n}(t)\right) \in C_{t}^{(1)}(R)$, we compose a matrix $U(h)$ defined along the first vector-integrals (12) with a representation of the form

$$
\begin{gathered}
U\left(h\left(\tau^{0}, \tau, t\right)\right)=\left(\begin{array}{c}
u^{T}\left(h_{1}\left(\tau^{0}, \tau, t\right)\right) \\
\ldots \\
u^{T}\left(h_{n}\left(\tau^{0}, \tau, t\right)\right)
\end{array}\right)= \\
=\left(\begin{array}{c}
\left(u_{1}\left(h_{1}\left(\tau^{0}, \tau, t\right)\right), \ldots, u_{n}\left(h_{1}\left(\tau^{0}, \tau, t\right)\right)\right) \\
\ldots \\
\left(u_{1}\left(h_{n}\left(\tau^{0}, \tau, t\right)\right), \ldots, u_{n}\left(h_{n}\left(\tau^{0}, \tau, t\right)\right)\right)
\end{array}\right)=\left(\begin{array}{c}
U_{1}\left(h_{1}\left(\tau^{0}, \tau, t\right)\right) \\
\ldots \\
U_{n}\left(h_{n}\left(\tau^{0}, \tau, t\right)\right)
\end{array}\right),
\end{gathered}
$$

where $u^{T}$ is transposed vector $u$. 
Now we construct the vector-function $x\left(\tau^{0}, \tau, t\right)$ using the scalar product of vector components of matrices (24) and (25), in the form

$$
x\left(\tau^{0}, \tau, t\right)=\left(\begin{array}{c}
\left\langle X_{1}\left(\tau-\tau^{0}\right), U_{1}\left(h_{1}\left(\tau^{0}, \tau, t\right)\right)\right\rangle \\
\ldots \\
\left\langle X_{n}\left(\tau-\tau^{0}\right), U_{n}\left(h_{n}\left(\tau^{0}, \tau, t\right)\right)\right\rangle
\end{array}\right) .
$$

By a direct check, we verify that the vector-function (26) is a solution to the initial problem $(7)-\left(7^{0}\right)$.

Now, to represent the solution (26) of system (7) as the product of matrix and initial vector-function $\left(7^{0}\right)$, we introduce the operator $P=\operatorname{diag}\left[P_{1}, \ldots, P_{n}\right]$, where $P_{j}$ acts on the vector-function $u(t)$ defined along the first integrals in the form

$$
P_{j} u_{k}\left(h\left(\tau^{0}, \tau, t\right)\right)=u_{k}\left(h_{j}\left(\tau^{0}, \tau, t\right)\right), \quad j, k=\overline{1, n} .
$$

Therefore, solution (26) can be represented as

$$
x\left(\tau^{0}, \tau, t\right)=P X\left(\tau-\tau^{0}\right) u\left(h\left(\tau^{0}, \tau, t\right)\right),
$$

where the matrices on the right are determined by the relations

$$
P X\left(\tau-\tau^{0}\right)=\left[x_{i j}\left(\tau-\tau^{0}\right) P_{i}\right]_{i, j=1}^{i, j=n}
$$

and

$$
\begin{gathered}
P X\left(\tau-\tau^{0}\right) u\left(h\left(\tau^{0}, \tau, t\right)\right)= \\
=\left[x_{i j}\left(\tau-\tau^{0}\right) P_{i} u_{j}\left(h\left(\tau^{0}, \tau, t\right)\right)\right]_{i, j=1}^{i, j=n}=\left[x_{i j}\left(\tau-\tau^{0}\right) u_{j}\left(h_{i}\left(\tau^{0}, \tau, t\right)\right)\right]_{i, j=1}^{i, j=n} .
\end{gathered}
$$

Indeed, the equivalence of relations (26) and (27) is visible from the following chains of transformations

$$
\begin{gathered}
P X\left(\tau-\tau^{0}\right) u\left(h\left(\tau^{0}, \tau, t\right)\right)=\operatorname{diag}\left[P_{1}, \ldots, P_{n}\right]\left(\left[x_{i j}\left(\tau-\tau^{0}\right)\right]_{1}^{n} u\left(h\left(\tau^{0}, \tau, t\right)\right)\right)_{i, j=1}^{i, j=n}= \\
=\operatorname{diag}\left[P_{1}, \ldots, P_{n}\right]\left(\sum_{k=1}^{n} x_{i k}\left(\tau-\tau^{0}\right) u_{k}\left(h\left(\tau^{0}, \tau, t\right)\right)\right)_{i=1}^{i=n}= \\
=\left(P_{i} \sum_{k=1}^{n} x_{i k}\left(\tau-\tau^{0}\right) u_{k}\left(h\left(\tau^{0}, \tau, t\right)\right)\right)_{i=1}^{i=n}=\left(\sum_{k=1}^{n} x_{i k}\left(\tau-\tau^{0}\right) P_{i} u_{k}\left(h\left(\tau^{0}, \tau, t\right)\right)\right)_{i=1}^{i=n}= \\
=\left(\sum_{k=1}^{n} x_{i k}\left(\tau-\tau^{0}\right) u_{k}\left(h_{i}\left(\tau^{0}, \tau, t\right)\right)\right)_{i=1}^{i=n}= \\
=\left(\left\langle X_{i}\left(\tau-\tau^{0}\right), U\left(h_{i}\left(\tau^{0}, \tau, t\right)\right)\right\rangle\right)_{i=1}^{i=n}=\left(\begin{array}{c}
\left\langle X_{1}\left(\tau-\tau^{0}\right), U_{1}\left(h_{1}\left(\tau^{0}, \tau, t\right)\right)\right\rangle \\
\ldots \\
\left\langle X_{n}\left(\tau-\tau^{0}\right), U_{n}\left(h_{n}\left(\tau^{0}, \tau, t\right)\right)\right\rangle
\end{array}\right) .
\end{gathered}
$$

Thus, based on the projector $P$, the solution of problem $(7)-\left(7^{0}\right)$ is determined by relation (27).

Lemma 1. The initial problem $(7)-\left(7^{0}\right)$ has a unique solution $x\left(\tau^{0}, \tau, t\right)$, which with the help of matricant $X(\tau)$ and projector $P$ is represented in the form of relation (27).

The existence of solution in the form (27) is justified above. Uniqueness follows from the existence of the matricant $X(\tau)$ of system (7). 
Theorem 2. Let system (1) satisfies condition (2). Then the system

$$
\frac{\partial y}{\partial \tau}+A \frac{\partial y}{\partial t}=B y
$$

has a solution $y=C x\left(\tau^{0}, \tau, t\right)$, where is the transformation matrix $(5), x\left(\tau^{0}, \tau, t\right)$ is the solution (27) of problem $(7)-\left(7^{0}\right)$.

The proof of Theorem 2 follows from the reducibility of system (28) to system (7) based on transformation (5).

Now we consider the initial problem for the nonhomogeneous system (6).

It is easy to verify that the vector-function

$$
x\left(\tau^{0}, \tau, t\right)=P X(\tau) u\left(h\left(\tau^{0}, \tau, t\right)\right)+\int_{\tau^{0}}^{\tau} P X(\tau) X^{-1}(s) f(s, h(s, \tau, t)) d s
$$

is a solution of system (6) with the initial condition $\left.x\right|_{\tau=\tau_{0}}=u(t) \in C_{t}^{(1)}(R)$.

Based on the transformation (5) from the representation (29), we have a solution of system (1) in the shape of

$$
y\left(\tau^{0}, \tau, t\right)=P C X(\tau) C^{-1} v\left(h\left(\tau^{0}, \tau, t\right)\right)+\int_{\tau^{0}}^{\tau} P C X(\tau) X^{-1}(s) C^{-1} \varphi(s, h(s, \tau, t)) d s,
$$

where $v(t)=C u(t)$.

Obviously, $C X(\tau) C^{-1}=Y(\tau)$ is a matricant of the homogeneous system (28) corresponding to system (1).

Then we obtain a representation of solution (30) using the matricant $Y(\tau)$ in the form

$$
y\left(\tau^{0}, \tau, t\right)=P Y(\tau) v\left(h\left(\tau^{0}, \tau, t\right)\right)+\int_{\tau^{0}}^{\tau} P Y(\tau) Y^{-1}(s) \varphi(s, h(s, \tau, t)) d s,
$$

satisfying the initial condition

$$
\left.y\right|_{\tau=\tau_{0}}=v(t) \in C_{t}^{(1)}(R) .
$$

When deriving formula (31), all its constituent parameters are uniquely determined.

Therefore, the solution (31) of system (1) with the initial condition $\left.y\right|_{\tau=\tau_{0}}=v(t)=C u(t)$ is unique, where $u(t) \in C_{t}^{(1)}(R)$.

Thus, the following Theorem 3 is proved.

Theorem 3. Let conditions (2) and (4) be satisfied. Then the initial problem (1)-( $\left.1^{0}\right)$ is uniquely solvable in the form of relation (31).

Note that the representation of solutions (31) implies the representations of solutions (23) and (27) of systems (19) and (7), respectively.

The essence of Theorem 3 is that the general solution of initial problem is defined as product of matricant and initial vector-function with certain directions of differentiation with respect to vector fields. 


\section{Multiperiodic solutions}

Lemma 2. Suppose all eigenvalues $\lambda_{j}(A), j=\overline{1, n}$ of matrix $A$ are real and non-zero, moreover $\omega$, $\lambda_{j} \theta, j=\overline{1, n}$, rationally incommensurable:

$$
\lambda_{j}(A) \neq 0, \quad \frac{\omega}{\lambda_{j} \theta} \notin Q, \quad j=\overline{1, n},
$$

where $Q$ is the set of rational numbers. Then, the $(\theta, \omega)$-periodic solutions of system (19), and, therefore, systems (20) and (21), are only constants.

Indeed, in order for the solution $x\left(\tau^{0}, \tau, t\right)$ be $(\theta, \omega)$-periodic, according to the structure of solutions (23) and the linearity characteristics $h_{j}\left(\tau^{0}, \tau, t\right)=t-\lambda_{j}\left(\tau-\tau^{0}\right), j=\overline{1, n}$ with respect to $\tau$ and $t$ the initial vector-function must be periodic with respect to $t$ both with the period $p \omega$ and the period $q_{j} \lambda_{j} \theta$ with integers $p$ and $q_{j}$. Then, by virtue of the incommensurability condition (32), $u(t)$ should only be constant.

Consider the set of solutions to system (7) with constant initial data $u=c$. Then we have solutions of the form

$$
x(\tau)=X(\tau) c, \quad c \text { is constant. }
$$

Theorem 4. Let condition (3) be satisfied. Then system (7) has only a zero $(\theta, \omega)$-periodic solution of the form (33).

Indeed, since $(\theta, \omega)$-periodic solutions of the form (33) satisfy the condition

$$
x(\tau+\theta)=X(\tau+\theta) c=X(\tau) X(\theta) c=X(\tau) c=x(\tau),
$$

then the vector $c$ guaranteeing $\theta$-periodicity of solution (33) is determined by the relation

$$
[X(\theta)-E] c=0 .
$$

It follows from (34) that the $(\theta, \omega)$-periodic solution of the form (33) of system (7), under condition (3), is only a trivial solution.

In fact, since $Y(\tau)=C X(\tau) C^{-1}$, from condition (3) we have

$$
\operatorname{det}[Y(\theta)-E]=\operatorname{det}\left[C X(\theta) C^{-1}-E\right]=\operatorname{det} C \operatorname{det}[X(\theta)-E] \operatorname{det} C^{-1} \neq 0 .
$$

Hence, $\operatorname{det}[X(\theta)-E] \neq 0$. Consequently, system (34) has only a zero solution, and from representation (33) we have $x=0$.

Theorem 4 is proved.

Theorem 4 can be formulated differently in the form of the following theorem.

Theorem $4^{\prime}$. For the system (7) hasn't a nonzero $\theta$-periodic solution it is necessary and sufficient that the following conditions are fulfilled

$$
\operatorname{det}[X(\theta)-E] \neq 0 \text {. }
$$

Theorem 5. If the condition (3) is not satisfied; then for the solution (33) of system (7) with a constant vector $c$ to be $\theta$-periodic with respect to $\tau$ it is necessary and sufficient that the vector $c$ be an eigenvector of the monodromy matrix $X(\theta)$ corresponding to its eigenvalue $\rho=1$.

Indeed, along with the nonzero solution (33), we consider the solution

$$
x(\tau+\theta)=X(\tau+\theta) c
$$

of system (7). From the theory of periodic solutions it is known that in order for the two solutions (33) and $\left(33^{\prime}\right)$ to coincide everywhere, it is necessary and sufficient that feasibility of condition

$$
x(\theta)=x(0) .
$$


Since $x(\theta)=X(\theta) c$ and $x(0)=c$, from this we have condition (34), which takes place in the presence of an eigenvalue $\rho=1$ of the monodromy matrix $X(\theta)$.

Theorem 5 is completely proved.

Theorem 6 . For system $(7)$ to has $(\theta, \omega)$-periodic with respect to $\tau$ solutions it is necessary and sufficient that the system of functional-difference equations

$$
P X(\theta) u(h(0, \theta, t))=u(t)
$$

to be solvable in the space of continuously differentiable $\omega$-periodic $n$-vector-functions

$$
u(t+\omega)=u(t) \in C_{t}^{(1)}(R)
$$

with the norm $\|u\|=\sup _{t \in R}|u(t)|$, where $|u(t)|$ is the Euclidean metric of vector $u$.

Indeed, at the same time with solution (27), we consider the solution

$$
\begin{gathered}
x(\tau+\theta, t+q \omega)=P X(\tau+\theta) u(h(0, \tau+\theta, t+q \omega))= \\
=P X(\tau) X(\theta) u(h(0, \tau+\theta, t)+q \omega), \quad q \in Z .
\end{gathered}
$$

From the definition of the $(\theta, \omega)$-periodic solutions $(27)$ of system $(7)$ with respect to $(\tau, t)$, we have

$$
P X(\tau) X(\theta) u(h(0, \tau+\theta, t)+q \omega)=P X(\tau) u(h(0, \tau, t)), \quad q \in Z .
$$

Supposing $\tau=0$, taking into account equality $P u(h(0,0, t))=P u(t)=u(t)$, from relation (38) we have $P X(\theta) u(h(0, \theta, t)+q \omega)=u(t)$. By virtue of property (37), we have $P X(\theta) u(h(0, \theta, t))=u(t)$, that is, condition (36) is established. Thus, the necessity of Theorem 6 is proved. Conversely, along with the solution

$$
x(\tau, t)=P X(\tau) u(h(0, \tau, t)),
$$

consider a solution of system (7) in the form

$$
\tilde{x}(\tau, t)=P X(\tau) X(\theta) u(h(0, \theta,(h(0, \tau, t))),
$$

where the initial conditions of these solutions are identical as $\tau=0$ by virtue of condition (36). Therefore, these solutions (39) and (40) coincide $\tilde{x}(\tau, t) \equiv x(\tau, t)$, and

$$
\begin{gathered}
\tilde{x}(\tau, t)=P X(\tau) X(\theta) u(h(0, \theta,(h(0, \tau, t))))=P X(\tau+\theta) u(h(0, \theta,(h(\theta, \tau+\theta, t))))= \\
=P X(\tau+\theta) u(h(0, \tau+\theta, t))=x(\tau+\theta, t) .
\end{gathered}
$$

It follows from (36) that the solution (39) is $\theta$-periodic.

Theorem 6 is completely proved.

Now we have the opportunity to generalize the Theorem 4' to the general case.

Theorem \%. Under condition (35), system $(7)$ has no $(\theta, \omega)$-periodic solutions except zero.

We prove Theorem 7 by contradiction method, assuming existence of a nonzero $(\theta, \omega)$-periodic solution $x^{*}(\tau, t)$ with initial function $x^{*}(0, t)=u^{*}(t)$, and $u^{*}(t+\omega)=u^{*}(t) \in C_{t}^{(1)}(R),\left|u^{*}\right|=\Delta^{*}>0$.

Obviously, for $t=t^{\prime}$ and $t=t^{\prime \prime}$ we have

$$
\left|u^{*}\left(t^{\prime}\right)-u^{*}\left(t^{\prime \prime}\right)\right|=\left|\frac{\partial u^{*}(\tilde{t})}{\partial t}\right|\left|t^{\prime}-t^{\prime \prime}\right| \leq l^{*}\left|t^{\prime}-t^{\prime \prime}\right|
$$

where $\tilde{t}=t^{\prime}+\alpha\left(t^{\prime \prime}-t^{\prime}\right), 0<\alpha<1, l^{*}=\left|\frac{\partial u^{*}(\tilde{t})}{\partial t}\right|$. 
Then, given that this solution is $p_{j} \theta$-periodic with respect to $\tau$ and $q_{j} \omega$-periodic with respect to $t$, on the basis of inequality (41) we have the estimate

$$
\begin{gathered}
\left|P_{j} u^{*}\left(h\left(0, p_{j} \theta, t\right)\right)-u^{*}(t)\right|=\left|u^{*}\left(t-\lambda_{j} p_{j} \theta\right)-u^{*}(t)\right|= \\
=\left|u^{*}\left(t+q_{j} \omega-\lambda_{j} p_{j} \theta\right)-u^{*}(t)\right| \leq l^{*}\left|q_{j} \omega-\lambda_{j} p_{j} \theta\right|, \quad q_{j}, p_{j} \in Z .
\end{gathered}
$$

Further, by virtue of rational incommensurable $\lambda_{j} p_{j} \theta$ and $\omega$, can choose $p_{j}$ and $q_{j}$ so that the estimate

$$
\left|q_{j} \omega-\lambda_{j} p_{j} \theta\right|<\delta
$$

is satisfied for any constant $\delta>0$.

Now, $(\theta, \omega)$-periodicity condition (36) for the solution $x^{*}(\tau, t)$ is written in the form

$$
\begin{gathered}
u^{*}(t)-P X(\theta) u^{*}(h(0, \theta, t))=\left[u_{i}^{*}(t)\right]_{i=1}^{n}-\left[\sum_{j=1}^{n} x_{i j}(\theta) u_{j}^{*}\left(t-\lambda_{i} \theta\right)\right]_{i=1}^{n}= \\
=\left[u_{i}^{*}(t)\right]_{i=1}^{n}-\left[\sum_{j=1}^{n} x_{i j}(\theta) u_{j}^{*}(t)\right]_{i=1}^{n}+\left[\sum_{j=1}^{n} x_{i j}(\theta) u_{j}^{*}(t)\right]_{i=1}^{n}-\left[\sum_{j=1}^{n} x_{i j}(\theta) u_{j}^{*}\left(t-\lambda_{i} \theta\right)\right]_{i=1}^{n}= \\
=\left[\sum_{j=1}^{n}\left\{\delta_{i j}-x_{i j}(\theta)\right\} u_{j}^{*}(t)\right]_{i=1}^{n}-\left[\sum_{j=1}^{n} x_{i j}(\theta)\left\{u_{j}^{*}\left(t-\lambda_{i} \theta\right)-u_{j}^{*}(t)\right\}\right]_{i=1}^{n}=0 .
\end{gathered}
$$

Therefore, from the last part of this identity we have

$$
[E-X(\theta)] u^{*}(t)=\left[\sum_{j=1}^{n} x_{i j}(\theta)\left\{u_{j}^{*}\left(t-\lambda_{i} \theta\right)-u_{j}^{*}(t)\right\}\right]_{i=1}^{n} .
$$

By condition (35), we obtain

$$
u^{*}(t)=[E-X(\theta)]^{-1}\left[\sum_{j=1}^{n} x_{i j}(\theta)\left\{u_{j}^{*}\left(t-\lambda_{i} \theta\right)-u_{j}^{*}(t)\right\}\right]_{i=1}^{n} .
$$

Based on inequality $\left(41^{\prime}\right)$, we have

$$
\begin{gathered}
\left|u^{*}(t)\right|=\left|[E-X(\theta)]^{-1}\right|\left[\sum_{j=1}^{n}\left|x_{i j}(\theta)\right|\left|u_{j}^{*}\left(t-\lambda_{i} \theta\right)-u_{j}^{*}(t)\right|\right]_{i=1}^{n} \leq \\
\leq\left|[E-X(\theta)]^{-1}\right||\bmod X(\theta)| \delta<\varepsilon .
\end{gathered}
$$

Therefore, $u^{*}=0$ which contradicts $\left|u^{*}\right|=\Delta^{*}>0$.

The obtained contradiction proves the rightness of Theorem 7 .

Theorem 8. If system (6) under condition (35) has a $(\theta, \omega)$-periodic solution, then it is unique.

Indeed, if the system under condition (35) has two different $(\theta, \omega)$-periodic solutions $x(\tau, t)$ and $\tilde{x}(\tau, t)$, then their difference $x(\tau, t)-\tilde{x}(\tau, t)=z(\tau, t)$ is a $(\theta, \omega)$-periodic solution of the corresponding homogeneous system (7). Under condition (35), it is trivial: $z(\tau, t)=0$. Consequently, $x(\tau, t) \equiv \tilde{y}(\tau, t)$. The resulting contradiction proves Theorem 8 . 
Theorem 9. Under the conditions $1^{0}-3^{0}$, system (6) admits a unique $(\theta, \omega)$-periodic solution $x^{*}(\tau, t)$, which is integrally represented by the formula

$$
x^{*}(\tau, t)=\left[X^{-1}(\tau+\theta)-X^{-1}(\tau)\right]^{-1} P \int_{\tau}^{\tau+\theta} X^{-1}(s) f_{\theta}(s, h(s, \tau, t)) d s,
$$

where vector-function $f_{\theta}(s, h(s, \tau, t))$ is determined by the relation

$$
f_{\theta}(s, h(s, \tau, t))=\left\{\begin{array}{l}
f(s, h(s, \tau, t)), \quad \tau \leq s \leq 0, \\
f(s, h(s, \tau+\theta, t)), \quad 0<s \leq \tau+\theta .
\end{array}\right.
$$

Indeed, suppose that $(\theta, \omega)$-periodic solution $x^{*}(\tau, t)$ has an initial function $x^{*}(0, t)=c^{*}$, where $c^{*}$ is constant vector. Then, according to Theorem 3 , it can be represented as

$$
x^{*}(\tau, t)=X(\tau) c^{*}+P X(\tau) \int_{\tau^{0}}^{\tau} X^{-1}(s) f(s, h(s, \tau, t)) d s .
$$

Along with this solution, we consider a solution

$$
x^{*}(\tau+\theta, t)=X(\tau+\theta) c^{*}+P X(\tau+\theta) \int_{\tau^{0}}^{\tau+\theta} X^{-1}(s) f(s, h(s, \tau+\theta, t)) d s .
$$

We write the system of representations (44) and (43) in the form

$$
\begin{gathered}
X^{-1}(\tau+\theta) x^{*}(\tau+\theta, t)=c^{*}+P \int_{\tau^{0}}^{\tau+\theta} X^{-1}(s) f(s, h(s, \tau+\theta, t)) d s, \\
X^{-1}(\tau) x^{*}(\tau, t)=c^{*}+P \int_{\tau^{0}}^{\tau} X^{-1}(s) f(s, h(s, \tau, t)) d s .
\end{gathered}
$$

Further, by replacing $s$ with $s+\theta$ under the integral $\left(44^{\prime}\right)$, we obtain the system

$$
\begin{gathered}
X^{-1}(\tau+\theta) x^{*}(\tau+\theta, t)=c^{*}+P \int_{\tau^{0}-\theta}^{\tau} X^{-1}(s) f(s, h(s, \tau+\theta, t)) d s, \\
X^{-1}(\tau) x^{*}(\tau, t)=c^{*}+P \int_{\tau^{0}}^{\tau} X^{-1}(s) f(s, h(s, \tau, t)) d s .
\end{gathered}
$$

Hence, taking into account that $x^{*}(\tau, t)=x^{*}(\tau+\theta, t)$, excluding the constant vector $c^{*}$, we have

$$
\left[X^{-1}(\tau+\theta)-X^{-1}(\tau)\right] x^{*}(\tau, t)=P \int_{\tau^{0}-\theta}^{\tau^{0}} X^{-1}(s) f(s, h(s, \tau, t)) d s .
$$

Consequently,

$$
x^{*}(\tau, t)=\left[X^{-1}(\tau+\theta)-X^{-1}(\tau)\right]^{-1} P \int_{\tau^{0}-\theta}^{\tau^{0}} X^{-1}(s) f(s, h(s, \tau, t)) d s .
$$


Since representation (45) is valid for all $\tau^{0}$, it remains valid when replaced $\tau^{0}$ with $\tau+\theta$, and the vector-function $f(s, h(s, \tau, t))$ is replaced by a vector function $f_{\theta}(s, h(s, \tau, t))$, which is determined by the relation $\left(42^{\prime}\right)$.

Therefore, we have the final representation of the $(\theta, \omega)$-periodic solution (42).

From the conditions $1^{0}-3^{0}$ follows the fulfillment of all the requirements of Theorems $6-8$. Therefore, system $(6)$ has no other $(\theta, \omega)$-periodic solutions except $(42)$.

Thus, when replacement (5), we obtain a solution of the main problem about the existence of a unique $(\theta, \omega)$-periodic solution $y^{*}(\tau, t)$ of system (1) in the form

$$
y^{*}(\tau, t)=\left[Y^{-1}(\tau+\theta)-Y^{-1}(\tau)\right]^{-1} P \int_{\tau}^{\tau+\theta} Y^{-1}(s) \varphi_{\theta}(s, h(s, \tau, t)) d s .
$$

where $Y(\tau)=C X(\tau)$, vector-function $\varphi_{\theta}(s, h(s, \tau, t))$ is determined by the relation

$$
\varphi_{\theta}(s, h(s, \tau, t))=\left\{\begin{array}{l}
\varphi(s, h(s, \tau, t)), \quad \tau \leq s \leq 0, \\
\varphi(s, h(s, \tau+\theta, t)), \quad 0<s \leq \tau+\theta .
\end{array}\right.
$$

Note that, based on Theorem 9, we have a theorem on solving the main problem.

Theorem 10. Under the conditions $1^{0}-3^{0}$, system (1) admits a unique $(\theta, \omega)$-periodic solution $y^{*}(\tau, t)$, which is integrally represented by the formula $(46)-\left(46^{\prime}\right)$.

In conclusion, we also note that the idea of work can be realized in the quasilinear case using the principle of compressed mappings.

\section{References}

1 Курант Р. Уравнения с частными производными / Р. Курант. - М.: Мир, 1964. - 830 с.

2 Рождественский Б.Л. Системы квазилинейных уравнений и их приложение к газовой динамике / Б.Л. Рождественский, Н.Н. Яненко. - М.: Наука, 1978. - 592 с.

3 Фарлоу С. Уравнения с частными производными для научных работников и инженеров / С. Фарлоу. - М.: Мир, 1985. - 384 с.

4 Харасахал В.Х. Почти периодические решения обыкновенных дифференциальных уравнений / В.Х. Харасахал. - Алма-Ата: Наука, 1970. - 200 с.

5 Умбетжанов Д.У. Почти многопериодические решения дифференциальных уравнений в частных производных / Д.У. Умбетжанов. - Алма-Ата: Наука, 1979. - 210 с.

6 Умбетжанов Д.У. Почти периодические решения эволюционных уравнений / Д.У. Умбетжанов. - Алма-Ата: Наука, 1990. - 184 с.

7 Vejvoda O. Partial differential equations: time-periodic solutions / O. Vejvoda, L. Herrmann, V. Lovicar, M. Sova, I. Straskaba, M. Stedry. - Springer Netherlands, 1982. - 358 p.

8 Сартабанов Ж.А. Периодты функциялар және кейбір қарапайым дифференциалдық теңдеулердің периодты шешімдері / Ж.А. Сартабанов. - Алматы: РБК, 2001. - 108 б.

9 Мухамбетова А.А. Устойчивость решений систем дифференциальных уравнений с многомерным временем / А.А. Мухабетова, Ж.А. Сартабанов. - Актобе: Принт А, 2007. - 168 с.

10 Кульжумиева А.А. Периодические решения систем дифференциальных уравнений с многомерным временем / А.А. Кульжумиева, Ж.А. Сартабанов. - Уральск: РИЦ ЗКГУ, 2001. $168 \mathrm{c}$.

11 Sartabanov Z.A. The multi-period solution of a linear system of equations with the operator of differentiation along the main diagonal of the space of independent variables and delayed arguments / Z.A. Sartabanov // AIP Conference Proceedings. - 2017. - Vol. 1880, 040020. DOI:10.1063/1.5000636. 
12 Sartabanov Z.A. Multiperiodic solutions of autonomous systems with operator of differentiation on the Lyapunov's vector field / Z.A. Sartabanov, B.Z. Omarova // AIP Conference Proceedings. - 2018. - Vol. 1997, 020041. DOI:10.1063/1.5049035.

13 Kulzhumiyeva A.A. On multiperiodic integrals of a linear system with the differentiation operator in the direction of the main diagonal in the space of independent variables / A.A. Kulzhumiyeva, Z.A. Sartabanov // Eurasian Mathematical Journal. - 2017. - Vol. 8, 1. - P. 67-75.

14 Kulzhumiyeva A.A. Integration of a linear equation with differential operator, corresponding to the main diagonal in the space of independent variables, and coefficients, constant on the diagonal / A.A. Kulzhumiyeva, Z.A. Sartabanov // Russian Mathematics. - 2019, Vol. 63, 6, C. 34-47. DOI: 10.3103/S1066369X19060045

15 Жакашбаев Б.Ж. О построении почти многопериодического решения одной системы уравнений в частных производных с треугольными матричными коэффициентами / Б.Ж. Жакашбаев, А.Б. Бержанов // Дифференциальные уравнения, теории функций и их приложения: сб. науч. тр. - Алма-Ата: Казах. гос. ун-т им. С.М. Кирова, 1986. - С. 38-40.

16 Кенжебаев К.К. Многопериодические решения квазилинейных гиперболических систем дифференциальных уравнений в частных производных / K.К. Кенжебаев, Ж.А. Сартабанов, А.У. Бекбауова // Матем. журн. - 2010. - Т. 10, № 1 (9). - С. 46-52.

17 Абдикаликова Г.А. О многопериодическом решении одной системы уравнений в частных производных / Г.А. Абдикаликова, А.Х. ЖКумагазиев // International Scientific Journal. 2016. - № 4. - С. 6-9.

18 Сартабанов Ж.А. Многопериодические решения линейных систем с постоянными коэффициентами и с двумя операторами дифференцирования / Ж.А. Сартабанов, Г.А. Абдикаликова, А.Х. Жумагазиев // Проблемы дифференциальных уравнений, анализа и алгебры (1 ноября 2018 г.): материалы VIII Междунар. науч. конф. - Актобе: Актюб. регион. гос. ун-т им. К. Жубанова, 2018. - С. 89-95.

19 Сартабанов Ж.А. Об одном методе исследования многопериодического решения системы с различными операторами дифференцирования / Ж.А. Сартабанов, А.Х. Жумагазиев, Г.А. Абдикаликова // Традиционная Междунар. апр. мат. конф. в честь Дня работников науки PK и Workshop «Problems of modelling processes in electrical contacts», посвящ. 80летнему юбилею акад. НАН РК С.Н. Харина: тез. докл. (3-5 апреля 2019 г.). - Алматы: Ин-т мат. и мат. моделирования КМ МОН РК, 2019. - С. 82-84.

20 Zhumagaziyev A.Kh. Multiperiodic solution of one hyperbolic system and its integral representation / A.Kh. Zhumagaziyev, Zh.A. Sartabanov, G.A. Abdikalikova // The Abstract Book of International Conference "Actual Problems of Analysis, Differential Equations and Algebra" (EMJ-2019), dedicated to the 10th anniversary of the Eurasian Mathematical Journal (October 16-19, 2019). - Nur-Sultan: L.N. Gumilyov Eurasian National University, 2019. - P. 99-101.

\author{
Ж.А. Сартабанов, Ә.Х. Жұмағазиев, Г.А. Абдикаликова
}

\title{
Тұрақты коэффициентті сызықты тар мағынадағы гиперболалық жүйенің көппериодты шешімі
}

\footnotetext{
Тар мағыналы гиперболалық сызықты тұрақты коэффициентті дифференциалдық теңдеулер жүйесінің барлық тәуелсіз айнымалылары бойынша көппериодты шешімінің бары мен жалғыздығы және оның матрица-интегралдық бейнеде өрнектеу мәселелері зерттелген. Осындай мақсатпен қарастырылып отырған, тәуелсіз айнымалылар кеңістігіндегі векторлық өрістердің бағыттары бойынша әртүрлі дифференциалдау операторлы жүйелер үшін дифференциалдау және интегралдау жүретін характеристикаларын анықтайтын проекторларға сүйенген, Кошидің сипаттауыштар әдісі негізінде бастапқы
} 
есептерді шешу тәсілі түзілген. Осы әдістеме бойынша біртекті және біртекті емес сызықты жүйелер үшін Коши есептері шешілді және интегралдық бейнесі келтірілді. Осы тұста енгізілген характеристикаларды анықтаушы проекторлардың маңызы шешуші болды. Негізгі есепті шешу барысында дифференциалдық операторлардың көппериодты нөлдерімен қатар біртекті сызықты жүйелердің нөлден өзге көппериодты шешімдерінің бар болуының қажетті және жеткілікті шарттары тағайындалды. Олардың негізінде, осы жүйелердің нөлдік емес көппериодты шешімдері болмайтын шарттар алынды. Нәтижесінде, біртекті сызықты жүйелердің нөлдік емес көппериодты шешімдері болмайтын жағдайда біртекті емес сызықты жүйелердің көппериодты шешімінің бар және жалғыз болуы туралы негізгі теорема дәлелдендеуімен қатар, оның проекциялау операторларымен байланысты интегралдық өрнегі қорытылып шығарылды. Қолданылған әдістемемен алынған нәтижелерді қарастырылған жүйенің жалпыланған квазисызықты жағдайында да, сондай-ақ, көпөлшемді $t=\left(t_{1}, \ldots t_{m}\right)$ векторы үшін және белгісіз вектор-функцияның дербес туындыларының жанындағы коэффициенттері көппериодты матрицалар болған кезде де осы әдісті қолданып алуға болады.

Kiлm сөздер: тар мағынадағы гиперболалық жүйе, көппериодты шешім, характеристикалар әдісі, проекциялау операторлары, векторлық өрістер бойынша дифференциалдау операторлары, интегралдық бейне.

Ж.А. Сартабанов, А.Х. Жумагазиев, Г.А. Абдикаликова

\section{Многопериодическое решение линейной гиперболической в узком смысле системы с постоянными коэффициентами}

Исследована задача о существовании и интегральном представлении в векторно-матричной форме единственного многопериодического по всем независимым переменным решения линейной гиперболической в узком смысле системы дифференциальных уравнений с постоянными коэффициентами. С целью решения поставленной задачи, на основе метода характеристик Коши, разработана методика построения решений начальной задачи для рассматриваемой системы с различными операторами дифференцирования по направлениям векторных полей пространства независимых переменных, основанная на проекторах, определяющих характеристики, по которым ведутся дифференцирование и интегрирование. По этой методике решены задачи Коши для линейной однородной и неоднородной систем с интегральным представлением. При этом существенное значение имели введенные проекторы по определению характеристик. По решению основной задачи, наряду с многопериодическими нулями операторов дифференцирования, установлены необходимые и достаточные условия существования многопериодических решений линейных однородных систем, отличных от тривиальных. Таким образом, получены условия отсутствия ненулевых многопериодических решений этих систем. В заключении, при отсутствии ненулевых многопериодических решений линейных однородных систем, доказана основная теорема о существовании и единственности многопериодического решения линейной неоднородной системы с выводом его интегрального представления, зависящего от операторов проектирования. Разработанная методика имеет перспективу распространения полученных результатов на квазилинейный случай рассматриваемой системы, а также на случаи многомерного вектора $t=\left(t_{1}, \ldots, t_{m}\right)$ и многопериодических матриц при частных производных искомой вектор-функции.

Ключевые слова: гиперболическая система в узком смысле, многопериодическое решение, метод характеристик, операторы проектирования, операторы дифференцирования по векторным полям, интегральное представление.

\section{References}

1 Kurant, R. (1964). Uravneniia s chastnymi proizvodnymi [Partial differential equations]. Moscow: Mir [in Russian].

2 Rozhdestvenskij, B.L., \& Janenko, N.N. (1978). Sistemy kvazilineinykh uravnenii i ikh prilozhenie $k$ hazovoi dinamike [Systems of quasilinear equations and their applications to gas dynamics]. Moscow: Nauka [in Russian]. 
3 Farlou, S. (1985). Uravneniia s chastnymi proizvodnymi dlia nauchnykh rabotnikov i inzhenerov [Partial Differential Equations for Scientists and Engineers]. Moscow: Mir [in Russian].

4 Kharasakhal, V.Kh. (1970). Pochti periodicheskie resheniia obyknovennykh differentsialnykh uravnenii [Almost periodic solutions of ordinary differential equations]. Alma-Ata: Nauka [in Russian].

5 Umbetzhanov, D.U. (1979). Pochti mnohoperiodicheskie resheniia differentsialnykh uravnenii $v$ chastnykh proizvodnykh [Almost multiperiodic solutions of partial differential equations]. AlmaAta: Nauka [in Russian].

6 Umbetzhanov, D.U. (1990). Pochti periodicheskie resheniia evoliutsionnykh uravnenii /Almost periodic solutions of evolution equations]. Alma-Ata: Nauka [in Russian].

7 Vejvoda, O., Herrmann, L., Lovicar, V., Sova, M., Straskaba, I., \& Stedry M. (1982). Partial differential equations: time-periodic solutions. Springer Netherlands.

8 Sartabanov, Zh.A. (2001). Periodty funktsiialar zhane keibir karapaiym differentsialdyk tendeulerdin periodty sheshimderi [Periodic functions and periodic solutions of some ordinary differential equations]. Alma-Ata: RBK [in Kazakh].

9 Mukhambetova, A.A., \& Sartabanov, Zh.A. (2007). Ustoichivost reshenii sistem differentsialnykh uravnenii s mnohomernym vremenem /Stability of solutions of the systems of differential equations with multidimensional time]. Aktobe: Print A [in Russian].

10 Kulzhumieva, A.A., \& Sartabanov, Zh.A. (2013). Periodicheskie resheniia sistem differentsialnykh uravnenii s mnohomernym vremenem /Periodic solutions of the systems of differential equations with multidimensional time]. Uralsk: RITs ZKHU [in Russian].

11 Sartabanov, Z.A. (2017). The multi-period solution of a linear system of equations with the operator of differentiation along the main diagonal of the space of independent variables and delayed arguments. AIP Conference Proceedings, Vol. 1880, 040020. Doi:10.1063/1.5000636

12 Sartabanov, Z.A., \& Omarova, B.Z. (2018). Multiperiodic solutions of autonomous systems with operator of differentiation on the Lyapunov's vector field. AIP Conference Proceedings, Vol. 1997, 020041. Doi:10.1063/1.5049035

13 Kulzhumiyeva, A.A., \& Sartabanov, Z.A. (2017). On multiperiodic integrals of a linear system with the differentiation operator in the direction of the main diagonal in the space of independent variables. Eurasian Mathematical Journal, Vol. 8, 1, 67-75.

14 Kulzhumiyeva, A.A., \& Sartabanov, Z.A. (2019). Integration of a linear equation with differential operator, corresponding to the main diagonal in the space of independent variables, and coefficients, constant on the diagonal. Russian Mathematics, Vol. 63, 6, 34-47. DOI: 10.3103/S1066369X19060045

15 Zhakashbaev, B.Zh., \& Berzhanov, A.B. (1986). O postroenii pochti mnohoperiodicheskoho resheniia odnoi sistemy uravnenii v chastnykh proizvodnykh s treuholnymi matrichnymi koeffitsientami [On the construction of an almost multiperiodic solution of a system of partial differential equations with triangular matrix coefficients]. Differentsialnye uravneniia, teorii funktsii $i$ ikh prilozheniia: sbornik nauchnykh trudov - Differential equations, function theory and their applications: the abstract book. (p. 38-40). Alma-Ata: Kazakhskii hosudarstvennyi universitet imeni S.M. Kirova [in Russian].

16 Kenzhebaev, K.K., Sartabanov, Zh.A., \& Bekbauova, A.U. (2010). Mnohoperiodicheskie resheniia kvazilineinykh hiperbolicheskikh sistem differentsialnykh uravnenii $\mathrm{v}$ chastnykh proizvodnykh [Multiperiodic solutions of quasilinear hyperbolic systems of partial differential equations]. $M a-$ tematicheskii zhurnal - Mathematical Journal, Vol. 10, 1, 46-52 [in Russian]. 
17 Abdikalikova, G.A., \& Zhumagaziyev, A.Kh. (2016). O mnohoperiodicheskom reshenii odnoi sistemy uravnenii $\mathrm{v}$ chastnykh proizvodnykh [On a multiperiodic solution of a system of partial differential equations]. International Scientific Journal, 4, 6-9 [in Russian].

18 Sartabanov, Zh.A., Abdikalikova, G.A., \& Zhumagaziyev, A.Kh. (2018). Mnohoperiodicheskie resheniia lineinykh sistem s postoiannymi koeffitsientami i s dvumia operatorami differentsirovaniia [Multiperiodic solutions of linear systems with constant coefficients and with two differentiation operators]. Problems of differential equations, analysis and algebra: VIII Mezhdunarodnaia nauchnaia konferentsiia (1 noiabria 2018 hoda) - Materials of VIII international scientific conference. (pp. 89-95). Aktobe: Aktiubinskii rehionalnyi hosudarstvennyi universitet imeni K. Zhubanova [in Russian].

19 Sartabanov, Zh.A., Zhumagaziyev, A.Kh., \& Abdikalikova, G.A. (2019). Ob odnom metode issledovaniia mnohoperiodicheskoho resheniia sistemy s razlichnymi operatorami differentsirovaniia [On one method of research of multiperiodic solution of system with various differentiation operators]. Traditsionnaia mezhdunarodnaia aprelskaia matematicheskaia konferentsiia $v$ chest Dnia rabotnikov nauki RK $i$ Workshop «Problems of modelling processes in electrical contacts», posviashchennaia 80-letnemu yubileiu akademika NAN RK Stanislava Nikolaevicha Harina (3-5 aprelia 2019 hoda) - Traditional International April Scientific Conference, in honor of the Day of Science Workers of RK and Workshop «Problems of modelling processes in electrical conacts» dedicated to the 80th anniversary of the academician of the NAS RK S.N. Kharin. (p. 82-84). Almaty: Institut matematiki i matematicheskoho modelirovaniia KN MON RK [in Russian].

20 Zhumagaziyev, A.Kh., Sartabanov, Zh.A., \& Abdikalikova, G.A. (2019). Multiperiodic solution of one hyperbolic system and its integral representation The Abstract Book of International Conference «Actual Problems of Analysis, Differential Equations and Algebra» (EMJ-2019), dedicated to the 10th anniversary of the Eurasian Mathematical Journal (October 16-19, 2019). (pp. 99-101). Nur-Sultan: L.N. Gumilyov Eurasian National University. 